Godina VII | Broj 14 | Sveska 2/2019 | ISSN 2334-816X
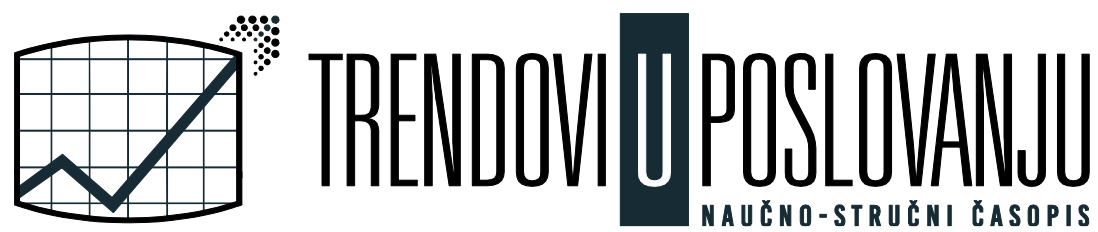

\author{
UPRAVLJANJE LJUDSKIM FAKTOROM U \\ POLJOPRIVREDI - MOTIVACIJA I KONTROLA
}

\title{
MANAGING THE HUMAN FACTOR IN AGRICULTURE - MOTIVATION AND CONTROL
}

Goran Lapčević | Visoka škola za poslovnu ekonomiju i preduzetništvo, Beograd, Republika Srbija | gorlap@gmail.com

Zorana Nikitović | Visoka škola za poslovnu ekonomiju i preduzetništvo, Beograd, Republika Srbija | zorana.nikitovic@vspep.edu.rs

UDK: 005.961:338.43

005.32:331.101.3

\section{Sažetak}

Poljoprivredna proizvodnja je najstarija privredna grana i koja ima posebno značajnu društvenu ulogu, da se prehrani svetska populacija, koja beleži kontinuirani porast. Zahvaljujući pre svega opštem društvenom, a posebno tehnološkom progresu, poljoprivreda je poslednjih 100 godina doživela dramatični rast produktivnosti, čime svoju ulogu uspešno ispunjava. Na poljoprivrednu proizvodnju uticaj ima veći broj faktora, od kojih su najznačajnijii ljudski, biološki, klimatski, poljoprivredno zemljište i drugi. Budući da je od navedenih faktora najznačajniji ljudski faktor, jer od njega zavisi unapređenje produktivnosti, uvećanje poljoprivredne proizvodnje i profita na poljoprivrednom zemljištu, to je od posebnog interesa da se izuči razumevanje ponašanja ljudskog faktora u radnom procesu. Stoga je u radu fokus na Teoriji planiranog ponašanja (TPP) ljudskog faktora i njegovoj motivaciji. Kod poljoprivrednih sistema kod kojih je ljudski faktor pod dovoljnom kontrolom, odnosno koji imaju dovoljno izgrađenu organizacionu strukturu, za motivaciju se preporučuju menadžerske Teorije motivacije. Kod poljoprivrednih sistema kod kojih ljudski faktor nije pod dovoljnom kontrolom, odnosno koji imaju nedovoljno razvijenu organizacionu strukturu ili kod kojih ona izostaje u potpunosti, za motivaciju se preporučuje Teorija samoodređenja (TSO), koja predstavlja nadogradnju TPP, a kojom se postiže objašnjenje predikcije ljudskog ponašanja.

\begin{abstract}
Agricultural production is one of the oldest industries and it has a particularly significant social role to feed the world's population, which is experiencing a steady increase. Thanks to the general social and technological progress, agriculture has experienced a dramatic productivity growth over the last 100 years, thus successfully fulfilling its role. Agricultural production is influenced by a number of factors, the most important being human, biological, climatic, of agricultural land and others. Since the most important human factor is one of these factors, as it depends on improving productivity, increasing agricultural production and profits on agricultural land, it is of particular interest to study the understanding of the human factor behavior in the work process. Therefore, the paper focuses on the Planned Behavior Theory of the human factor and its motivation. In agricultural systems in which the human factor is under sufficient control, that is, with a sufficiently constructed organizational structure, managerial motivation theories are recommended for motivation. For agricultural systems where the human factor is not under sufficient control, that is, they have insufficiently developed organizational structure or in which it is completely lacking, selfdetermination theory, which is an upgrade of the Planned Behavior Theory, which provides an explanation of prediction of human behavior.
\end{abstract}

Ključne reči: poljoprivreda, ljudski faktor, upravljanje, teorije, planirano ponašanje, samoodređenje Keywords: agriculture, human factor, management, theories, motivation, planned behavior, self-determination JEL Klasifikacija:O15 


\section{Uvod}

Poljoprivreda je nakon lova prva privredna grana koja se razvila pre više od 10.000 godina kroz uzgoj prvih kultura na Bliskom istoku, u severnoj i južnoj Kini, afričkom Sahelu, Novoj Gvineji, u Srednjoj i Južnoj Americi, a nakon čega je prošla kroz značajan razvoj. Prve agrotehničke mere kao što su navodnjavanje, plodored, đubrivo i pesticidi su se takođe davno razvile, ali značajan napredak one beleže tek u poslednja dva veka.

U 20. veku poljoprivredu je karakterisala povećana produktivnost, zamena ljudskog rada mašinskim, masovna primena sintetičkih đubriva i pesticida, selektivan uzgoj i primena mehanizacije u proizvodnji.

U 21. veku razvoj poljoprivrede prevashodno se odnosi na digitalizaciju, ali i na politička pitanja od kojih su najznačajnija ona koja se tiču ekologije (zagađenje vazduha i vode, biogoriva, genetski modifikovani organizmi, i drugo), ali drugih kao što su carinske tarife i poljoprivredne subvencije, a u poslednje vreme posebno u razvijenim zemljama pitanje ,povratka prirodi” kroz organsku poljoprivredu [1].

Društveni, a posebno tehnološki progres je između ostalog, u značajnoj meri oblikovao i razvoj poljoprivredne proizvodnje, čime je sa jedne strane omogućio dramatični rast produktivnosti, a sa druge strane još više produbio jaz između razvijenih i nerazvijenih zemalja.

Od 1961. godine do danas broj stanovnika na zemlji se udvostručio, približavajući se broju od 7,5 milijardi ljudi, pri čemu primat preuzima urbano (gradsko) stanovništvo (55\%) nad ruralnim (seoskim) stanovništvom (45\%) [2] .

Mada poljoprivreda zajedno sa srodnim aktivnostima duž lanaca proizvodnje hrane i dalje ostaje ključna mogućnost prihoda za siromašne i ugrožene grupe stanovništva, procentualno učešće zaposlenih u poljoprivredi beleži konstantan pad u ukupnoj strukturi zaposlenih.

Plodno zemljište opada na račun urbanog širenja, broj zaposlenih u poljoprivredi opada, a poljoprivredna proizvodnja se ipak uvećava jer se produktivnost povećava, što svedoči o tome da su se metode poljoprivredne proizvodnje značajno promenile.

Na razvoj poljoprivrede ključni uticaj imaju dve komponente. Tehnologija je prva od značajnih komponenata razvoja poljoprivrede, dok drugu komponentu čine ljudi, bilo da su sa strane poljoprivredne proizvodnje ili sa strane konzumenata, odnosno krajnjih korisnika poljoprivrednih proizvoda. Ova komponenta razvoja poljoprivrede od posebnog je značaja za povećanje poljoprivredne produktivnosti, a realizuje se kroz uvođenje poboljšanih sistema upravljanja u poljoprivredi.

U Republici Srbiji poljoprivreda je omeđena sledećim radno - zakonodavnim okvirom [3]. Poljoprivreda je privredna delatnost koja obuhvata biljnu i stočarsku proizvodnju i s njima povezane uslužne delatnosti, integriše dve osnovne grane poljoprivrede - zemljoradnju i stočarstvo, a zajedno sa šumarstvom, lovom i ribolovom spada u primarni sektor privrede. Pod poljoprivrednom proizvodnjom se podrazumeva proces proizvodnje biljnih i stočarskih proizvoda, uzgajanje riba, pčela, ubiranje i/ili uzgoj pečuraka, puževa, proizvodnja začinskog i lekovitog bilja i dr. koja se obavlja na poljoprivrednom zemljištu. Poljoprivredno gazdinstvo je poslovni system, odnosno proizvodna jedinica na kojoj privredno društvo, zemljoradnička zadruga, ustanova ili drugo pravno lice, preduzetnik ili poljoprivrednik obavlja poljoprivrednu proizvodnju.

Ovaj rad se bavi onom komponentom razvoja poljoprivrede koji se tiče unapređenja sistema upravljanja u poljoprivredi. U tom smislu u radu se detaljnije razmatraju pitanja ponašanja ljudi u poljoprivredi, odnosno kako se tim ponašanjem može svrsishodno upravljati.

$\mathrm{U}$ radu se najpre definiše ljudski faktor u poljoprivredi. Potom se detaljinije razmatraju bihejvioralne studije, i u tom smislu posebno Teorija planiranog ponašanja (TPP). U cilju daljeg unapređenja teorije, fokus razmatranja se prenosi na motivaciju, koja se dalje razmatra sa procesnog 
stanovišta, da bi se došlo i do menadžerske Teorije radne motivacije. Na kraju se TPP dopunjava komponentom motivacije čime se gradi konačni model Teorije samoodređenja (TSO), koji se koristi za tumačenje motivacije ljudskog faktora u jednom velikom delu poljoprivrede.

\section{Ljudski faktor u poljoprivredi}

Na poljoprivrednu proizvodnju upliv ima veći broj faktora, od kojih bi se mogli izdvojiti sledeći: ljudski, biološki, klimatski, poljoprivredno zemljište (tlo) i drugi faktori. Nesumnjivo je, da je od navedenih faktora, u poljoprivredi najznačajniji ljudski faktor, budući da u konačnom ishodu sve od njega zavisi. Mogu da budi ispunjeni povoljni svi ostali faktori, ali ako sa strane ljudskog faktora nema volje, znanja i sposobnosti, rezultat oživotvoren u predelima zasađenim poljoprivrednim kulturama i potonjim žetvama će izostati, jer su upravo zasađeni poljoprivredni predeli rezultat ljudskih aktivnosti.

Značaj ljudskog faktora ogleda se u tome što on omogućava kompenzovanje preostalih faktora kroz [4]:

- Rast populacije,

- Tehnološki progres,

- Društvenu organizaciju.

Rast populacije. Kako svetska populacija raste povećava se potreba za uvećanjem obradivog zemljišta (za uzgoj useva i za pašu stoke). U tom smislu ljudski faktor menja okruženje čime utiče na prirodnu vegetaciju i održivost bio diveziteta. Stoga navedene promene u pejzažu ako nisu kontrolisane i prekomerna eksploatacija resursa mogu da izazovu ozbiljne probleme za životnu sredinu i životinjske vrste.

Tehnološki napredak. I dalje postoji velika razlika između tradicionalnih načina obrade zemljišta u nedovoljno razvijenim područjima i moderne poljoprivrede u razvijenim zemljama. Razlika se ogleda najpre u vrsti primenjenih alata a potom i u vrsti, broju i novu primenjenih agrotehničkih mera. Kod tradicionalnih načina obrade zemljišta u primeni su jednostavni alati (ralo, motika, srp i kosa, plug,...), a primena agrotehničkih mera je nedovoljna ili u potpunosti izostaje, čime je produktivnost izrazito niska. Kod moderne poljoprivrede primenjuju se mehanizovani i danas sve više sofisticirani alati za obradu zemlje (traktori, kombajni, GPS, računari) koje prati kompleks agrotehničkih mera (hemijska đubriva i pesticidi, navodnjavanje, staklenici, staje za stoku...) čime se ostvaruje izuzetna produktivnost, koja u konačnom na globalnom nivou kompenzuje nedostatke tradicionalne proljoprivrede.

\section{Društvena organizacija se manifestuje kroz:}

- socijalno i ekonomsko usmeranje, odnosno ekonomija za život (proizvodnja hrane za vlastite potrebe kroz svaštarstvo, tj. uzgoj većeg broja različitih poljoprivrednih kultura) kao i tržišna ekonomija (koja se manifestuje kroz proizvodnju hrane zasnovanu na viškovima za prodaju i na specijalizaciji za određene kulture).

- sistem vlasništva nad zemljištem, odnosno privatno vlasništvo (pojedinca, kompanije ili zadruge) kao i kolektivno vlasništvo (društvene zajednice - plemena, lokalne zajednice, države).

- kategorizaciju zemljišta prema veličini, odnosno podelu na velike poljoprivredne posede, posede srednje veličine, i mala gazdinstva.

- sistem poljoprivredne proizvodnje koji se tiče angažovanih u poljoprivredi, odnosno direktni sistem kod koga je vlasnik i sam angažovan ili unajmljuje druge radnike kao i indirektni sistem kod koga zemlju obrađuju druge osobe bilo u zamenu za plaćanje (putem iznajmljivanja) ili $\mathrm{u}$ zamenu za procenat proizvodnje (kroz udeo $\mathrm{u}$ poljoprivredi). 
Ljudski faktor u poljoprivredi obuhvata ljudske karakteristike koje utiču na način donošenja odluka i sprovođenje operacija u poljoprivredi. Ključne karakteristike ljudskog faktore čine [5]:

- Nivo obrazovanja (izražen kroz veštine zaposlenih) i tehnologija (izražena kroz tehnološki progres),

- Zdravlje ljudi (koje se manifestuje kroz uticaj na njihovu snagu, potencijal, viziju i odlučnost za rad),

- Ekonomija (koje se manifestuje kroz održavanje ekonomske stabilnosti u zemlji),

- Politika vlade (koja se sprovodi kroz predlaganje zakona koji štite poljoprivrednike, zemlju i stoku i dr.),

- Transport i komunikacije (kojim se sprovodi transfer poljoprivrednih dobara od farmi do krajnjih potrošača),

- Kulturne prakse i religiozna verovanja (koja se manifestuju kroz aktivnosti kojima se otklanjaju prepreke važnim promenama u društvu a koje doprinose razvoju poljoprivrede),

- Tržišne snage (koje se obezbeđuju kroz razvoj zdrave konkurencije na tržištu).

Ljudski faktor nije prisutan samo u poljoprivrednoj proizvodnji, već se javlja i kao konzument, odnosno krajnji korisnik poljoprivrednih proizvoda. Budući da ljudi imaju određeno ponašanje, koje je uslovljeno društvenim normama i subkulturom, to će i njihova prihvatljivost novih tehnologija koje su značajne za dalji rast produktivnosti (difuzija inovacija) zavisiti od promene ponašanja farmera, koje određuju njihove norme, uverenja i stavove. Stoga je razumevanje ponašanja ljudskog faktora ključno za povećanje poljoprivredne proizvodnje kao i profita ostvarenog na poljoprivrednom zemljištu. Otuda je razumljivo usmerenje poljoprivrednih eksperata ka ekspertima društvenih nauka, u cilju iznalaženja zakonitosti ponašanja farmera, a sve radi boljeg razumevanja mehanizama koji stoje u osnovi usvajanja nove tehnologije (difuzija inovacija).

Proces poslovanja u poljoprivredi odvija se svrsishodnim kombinovanjem ljudskog faktora (radne snage), sa ostalim faktorima poljoprivredne proizvodnje (plodno tlo, mehanizacija, hemijska sredstva, semenska roba, gorivo i dr.). Kako ljudski faktor predstavlja skup umnih i fizičkih sposobnosti čoveka za rad koje su neodvojive od njegove ličnosti, upravljanje ljudskim faktorom je usko povezano sa ulogom individue $\mathrm{u}$ funkcionisanju poljoprivrednog organizacionog sistema.

Kada je u pitanju ljudski faktor u poljoprivredi nikako ne treba potceniti i lični rizik vlasnika malih gazdinstava u poljoprivredi, a koji obuhvata sledeće elemente [6]:

- "Poljoprivredna proizvodnja je tradicionalno rizično zanimanje".

- Lični rizik je jedno od pet (šest) polja rizika u poljoprivrednoj proizvodnji.

- Isti tip rizika postoji i u svim drugim delatnostima kada su u pitanju preduzetnici i njihovi zaposleni.

- Menadžment je ključni input.

- Često se zanemaruje od strane poljoprivrednika.

U tom smislu, kada se radi o malim gazdinstvima, rizik u poljoprivrednoj proizvodnji može se tretirati na gotovo isti način kao što je to slučaj kada je u pitanju rizik preduzetničkog poduhvata [7].

Za ljudski faktor u poljoprivredi od posebnog značaja je kako se njime upravlja, odnosno da li je pod dovoljnom kontrolom kao i u kojoj meri poljoprivredni poslovni sistem, kome on pripada, ima izgrađenu organizacionu strukturu. 
Upravljanje (menadžment) ljudskim faktorom se, prema [8], može definisati kao "aktivnost usmerena na pribavljanje, korišćenje, razvoj i održavanje visokih performansi ljudskog faktora."

Drugim rečima upravljanje ljudskim faktorom (radnom snagom) u poljoprivredi je proces koji integriše sledeće aktivnosti:

- Analiza radnog mesta i opis.

- Zapošljavanje.

- Uvođenje u posao i obuka.

- Izgradnja odnosa poslodavac - zaposleni.

- Ocena radnih karakteristika.

- Adekvatna nadoknada.

- Disciplina.

\section{Teorija planiranog ponašanja (TPP)}

$\mathrm{Na}$ osnovu istraživanja ljudskog ponašanja, koje je uzelo u obzir relevantne faktore (strukturne, eksterne i ograničenja) za akciju, socijalni psiholozi su razvili bihejvioralne modele za razumevanje i predviđanje ljudskog ponašanja.

Kada je poljoprivreda u pitanju, od interesa su dva pristupa u bihejvioralnim studijama, i to Teorija planiranog ponašanja (TPP) i Teorija samoodređenja (TSO), tek čijom punom integracijom se postiže objašnjenje predikcije ljudskog ponašanja malih poljoprivrednih gazdinstava, odnosno u delu nekorporativne poljoprivrede.

Teorija planiranog ponašanja (TPP), slika 1, nastoji da razume i predvidi ponašanje u slučaju nepotpune kontrole ljudskog faktora, a što je tipičan slučaj malih poljoprivrednih gazdinstava.

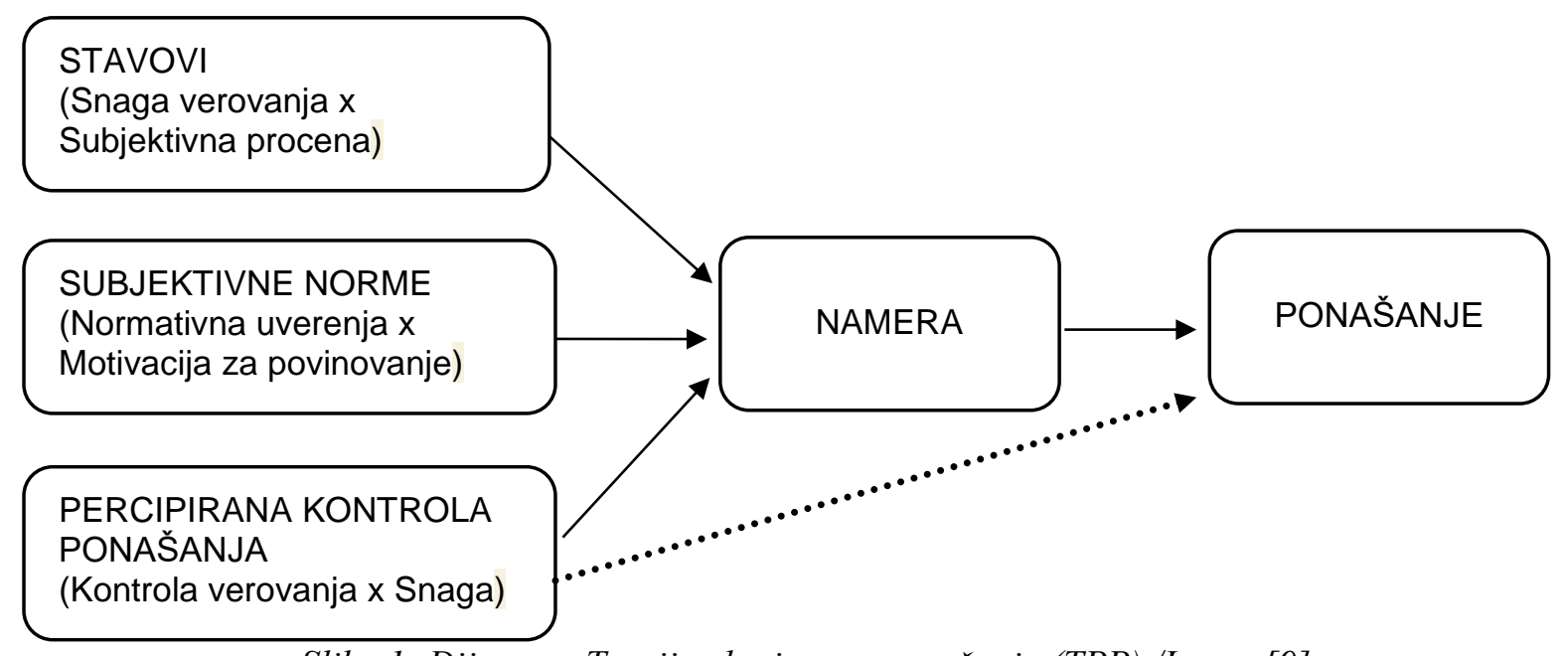

Slika 1: Dijagram Teorije planiranog ponašanja (TPP) /Izvor: [9]

Prema TPP nameravano ponašanje individue je funkcija tri komponente [9]:

- ličnih stavova individue, koji grade multiplikovanu komponentu koja se sastoji od snage verovanja povezane sa ponašanjem i subjektivnom procenom ishoda individue).

- subjektivnih normi, koje se odnose na normativna uverenja, tj. percepciju individue o društvenim pritiscima i motivaciji za povinovanje, tj. o tome da li treba ili ne treba da se angažuje, odnosno povinuje određenom ponašanju. 
- percipirane kontrole ponašanja (PBC), koje se odnose na percepciju individue o tome u kojoj meri je dato ponašanja lako ili teško, i što individua više percipira da ima kontrolu, to je veća verovatnoća da će se uključiti u ponašanje.

- Primena TPP u oblasti poljoprivrede je već pokazala obećavajuće rezultate. Do sada je TPP, ili iz nje izvedeni modeli, uspešno primenjena u više različitih istraživanja i u više različitih zemalja, ali je takođe ispoljila i izvesne slabosti. U cilju otklanjanja navedenih slabosti modelu je dodat još jedan potencijalni faktor - motivacija.

\section{Motivacija}

Svrsishodno ponašanje čoveka u radnom procesu, istorijski posmatrano, rezultat je delovanja na njega socijalno-ekonomskog ambijenta, kako bi se ostvarila njegova zadovoljavajuća radna aktivnost. Suprotnost tom ponašanju je nerad, koji je, osim u slučajevima odmora od napornog rada, neprihvatljiva alternativa.

Sa stanovišta motivacije s pravom se može postaviti pitanje: Šta je to što jednu individuu pokreće na aktivnost, šta tu aktivnost usmerava, održava i obustavlja? Odgovor na navedeno pitanje je: motiv.

Motiv, prema [10], podrazumeva unutrašnji psihički faktor, koji pokreće, usmerava, održava i obustavlja ljudsku aktivnost. U pozadini svakog motiva stoji neka ljudska potreba koja traži da bude zadovoljena, kako bi se održalo stanje ravnoteže bioloških funkcija njegovog organizma, koje se naziva homeostaza. Svako odstupanje od homeostaze odražava se na ponašanje pojedinca u cilju njenog nanovnog uspostavljanja. Može se konstatovati da je mehanizam koji pokreće individuu na aktivnost zapravo poremećaj homeostaze.

Motivacija, prema [11], je "sila" koja pokreće i održava individuu na ostvarivanju ponašanja, koje će omogućiti zadovoljenje želja, potreba, interesa. Motivacija je proces u čoveku koji ga pokreće prema nekom cilju [12].

Motivacija, slika 2, predstavlja proces promenljivog inteziteta koji traje sve dok se ne postigne adekvatno zadovoljenje, ili ne prestane interes (voljno ili prinudno), a tokom njegovog odvijanja postoji snažan upliv uticajnih faktora iz okruženja, koji mogu proizvesti potencirajuće, neutralno ili negativno orijentisano delovanje.

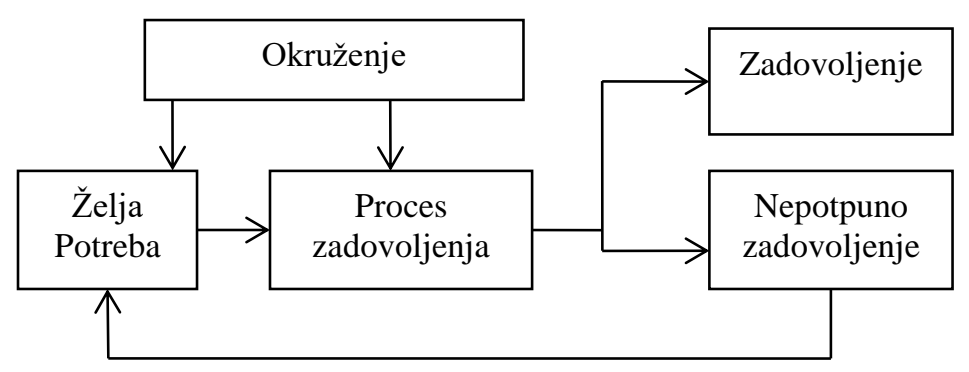

Slika 2. Struktura procesa motivacije [11]

Proces motivacije započinje željom, odnosno potrebom, i u okviru datih unutrašnjih i spoljašnjih uslova, odvija se kroz proces zadovoljenja koji za rezultat ima potpuno zadovoljenje, odnosno svrsishodno ponašanje, ili nepotpuno zadovoljenje, u kom slučaju se proces obnavlja. 


\subsection{Proces radne motivacije}

Proces radne motivacije je u bitnim elementima većim delom nevidljiv sa strane i odvija se kroz psiho-fiziološko proživljavanje svake individue, a vidljivo je samo ponašanje na radu, slika 3. Ako se proces motivacije primeni na radno angažovanje individue, tada je razlog, odnosno motiv za određeno ponašanje, neodvojiv od ponašanja koje će uslediti nakon što se zadovolji potreba.

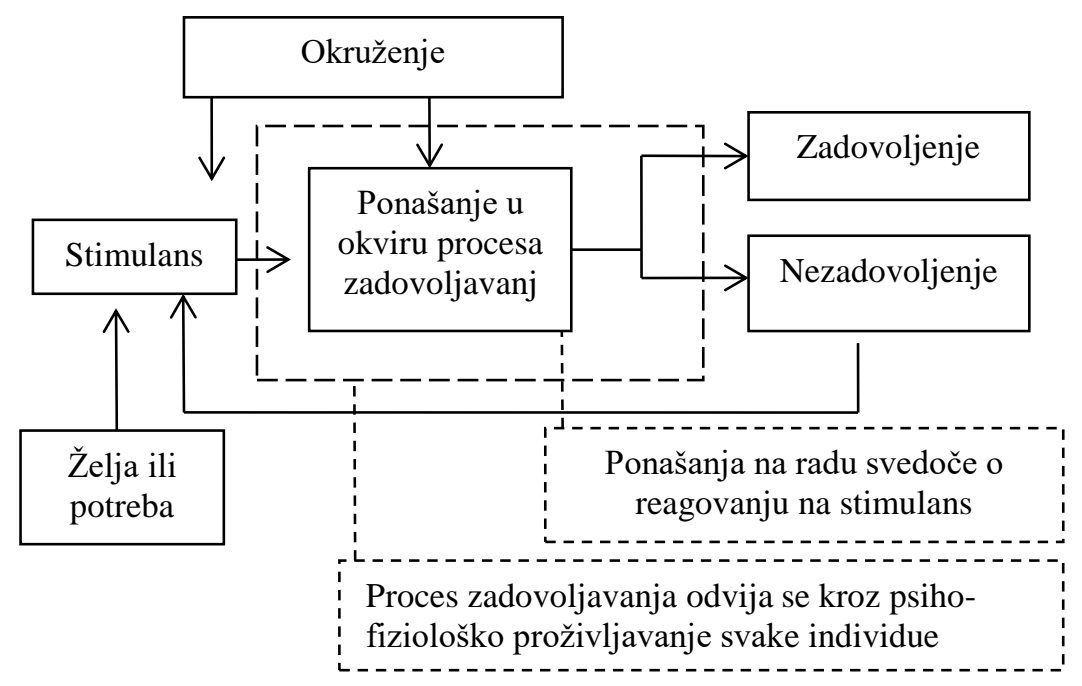

Slika 3. Struktura procesa radne motivacije [Izvor: [11]

Na primer, pri obavljanju teškog fizičkog posla gladan čovek će u većoj meri usmeriti svoju pažnju na hranu, a znatno manje na druge aktivnosti, što znači da motivi deluju selektivno u pravcu prioritetnog zadovoljenja primarne potrebe. U ovom primeru glad je stimulans, odnosno pokretač, predstavlja ponašanje individue u okviru procesa zadovoljenja gladi, $i$ ako je uzeta dovoljna količina hrane, rezultat će biti sitost, odnosno zadovoljenje, u suprotnom rezultat će biti nezadovoljenje, odnosno nastavak delovanja potrebe.

Pri razmatranju procesa radne motivacije, treba imati u vidu sledeće činjenice, i to [11]:

- $\quad$ svaki pojedinac radno se ponaša podstaknut samo njemu znanim razlozima, budući da se motivi razlikuju od osobe do osobe;

- radno ponašanje pojedinca podleže promenama tokom vremena, usled razvoja ličnosti, sticanja iskustva, dodatnog informisanja i drugih okolnosti.

- Potrebe, posledično i stimulansi mogu biti urođeni i stečeni. Urođeni stimulansi su rezultat delovanja psiho-fizioloških i/ili socioloških potreba, koje omogućavaju život i funkcionisanje čoveka pod normalnim uslovima. Stečeni stimulansi su rezultat interakcije čoveka sa okruženjem i pojavljuju se u raznim sadržajima, zavisno od stepena razvijenosti umnih i fizičkih potencijala individue, kao i/ili zavisno od kulturne, ekonomske, socijalne razvijenosti okruženja.

Potrebe, posledično i stimulansi u pogledu vremenskog određenja mogu biti ograničenog, periodičnog i kontinuiranog vremenskog trajanja.

Sama pojava neke želje, odnosno potrebe, po sebi ne znači automatski i promenu ponašanja individue. Promena ponašanja individue nastupa tek onda kada želja, odnosno potreba, dostigne određeni intenzitet koji se naziva nivo pokretačkog potencijala, slika 4. 


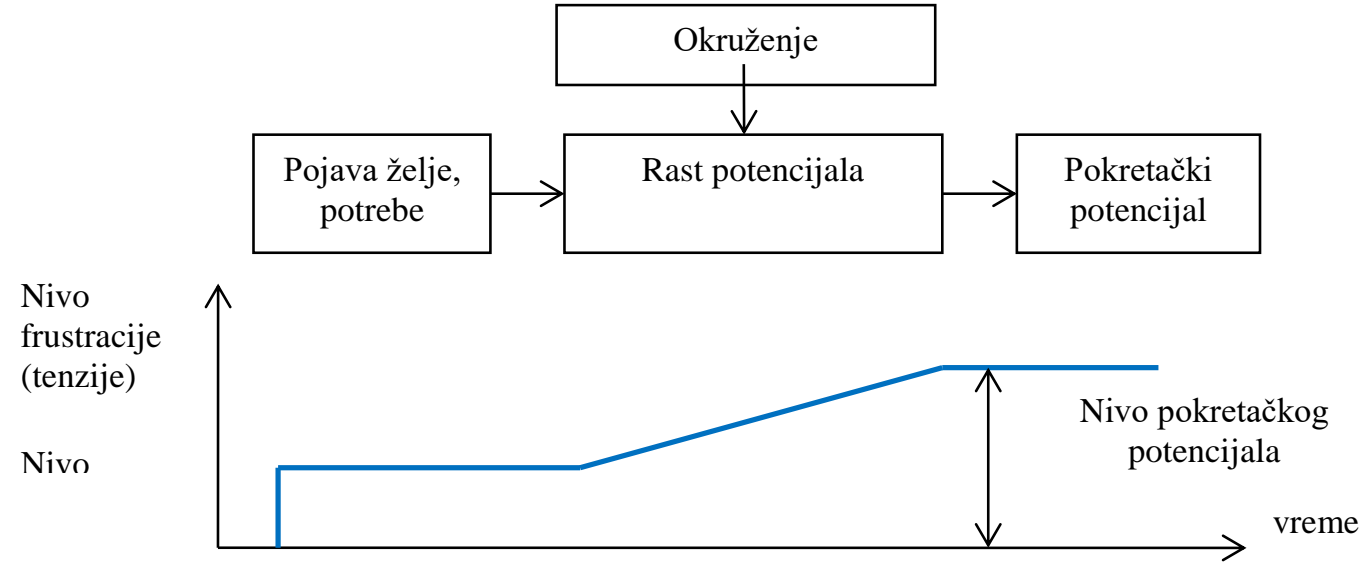

Slika 4. Model pokretačkog potencijala [Izvor: [11]

Postizanje svrsishodnog radnog ponašanja od strane individue uslovljeno je kumuliranjem frustracija odnosno tenzija usled izvesne prepreke koja sprečava da se zadovolji određena potreba individue, do nivoa pokretačkog potencijala, koji je individualan, i koji zavisi od sistema vrednosti individue, stepena zainteresovanosti individue, svesne (kao i podsvesne) procene ličnih osobina $u$ pogledu vlastitih sposobnosti od strane individue, iskustva, potrebnih znanja, eventualnih rizika, relevantnih uslova, kao i upuštanja u zadovoljavanje odgovarajuće želje.

Nivo pokretačkog potencijala razlikuje se od jedne do druge individue i nalazi se u rasponu od nedovoljno, pa do izuzetno motivisanog zadovoljavanja odgovarajuće želje, odnosno potrebe.

U okviru procesa radne motivacije, slika 4 , nosilac želje, potrebe, i svrsishodnog ponašanja je individua koja je kompetentna, koja poseduje umni (znanje i veštine) i fizički (predispozicije) potencijal. Procena kompetencija ima izuzetan značaj kod dobijanja uvida u kapacitete zaposlenih, njihove potencijale i ograničenja radi što preciznijeg predviđanja njihovog individualnog uspeha ili timskog uspeha [13]. Prema tome ukupne radne potencijale jedne individue čine:

- znanje,

- iskustvo,

- sposobnost za aktiviranje znanja i iskustva,

- fizička spremnost.

Radni potencijal osobe se tokom protoka vremena menja u zavisnosti od individualnih sklonosti, sposobnosti, kao i okolnosti. Neke se sposobnosti delom nasleđuju, dok se najveći broj razvija putem studiranja i obrazovanja [14]. Radom se stiču nova iskustva, vremenom se stiču nove informacije (na primer kontinuirano obrazovanje), proširuju se i produbljuju prethodna znanja, dok se fizički potencijal individue menja na više, odnosno na niže u zavisnosti od vrste posla, dodatnog uvežbavanja, kao i hronološkog starenja [11].

\subsection{Teorije radne motivacije}

Sa menadžerskog, odnosno korporativnog stanovišta, do sada je razvijena Teorija radne motivacije (TRM) koja se uslovno može podeliti u dve grupe teorija, i to [15]:

Teorije potreba, od kojih bi se, između ostalih, posebno mogle izdvojiti:

- Hijerarhija potreba (A. Maslow),

- $\quad \mathrm{ERG}$ - teorija (C. Alderfer ),

- Teorija stečenih potreba (Mc Clelland),

- Dvo-faktorska teorija (F. Herzberg). 
Teorije održavanja i unapređenja radnog ponašanja, od kojih bi se, između ostalih, posebno mogle izdvojiti:

- Teorija očekivanja (V. Vroom),

- Teorija pojačavanja (B. F. Skinner),

- Teorija pravičnosti (S. J. Adams),

- Teorija postavljenih ciljeva (E. A. Locke i G. P. Latham).

Navedene teorije imaju prevashodni značaj kada se radi o motivaciji u slučaju korporativnog menadžmenta, i u poljoprivredi se mogu primeniti u slučaju motivacije u korporativnoj poljoprivredi.

Međutim, kada je u pitanju motivacija malih gazdinstava u poljoprivredi, odnosno kod nepotpune kontrole, mnogo je efektivnije da se primeni Teorija samoodređenja (TSO) / Self Determination Theory (SDT)/.

U tom smislu TSO je ključni sistem za razumevanje motivacije koji je proizašao iz voljnog ponašanja individue, i koji u osnovi razlikuje četiri kategorije nivoa regulacije, od eksterne (external regulation) do unutrašnje (intrinsic regulation) motivacije, Tabela 1.

Tabela 1: Tipovi motivacije prema TSO /Izvor: [15]

\begin{tabular}{|l|l|l|l|l|}
\hline Tip motivacije & \multicolumn{2}{|l|}{$\begin{array}{l}\text { Eksterna } \\
\text { Motivacija }\end{array}$} & $\begin{array}{l}\text { Unutrašnja } \\
\text { motivacija }\end{array}$ \\
\hline Tip regulacije & $\begin{array}{l}\text { Eksterna } \\
\text { regulacija }\end{array}$ & $\begin{array}{l}\text { Uvedena } \\
\text { regulacija }\end{array}$ & $\begin{array}{l}\text { Identifikovana } \\
\text { regulacija }\end{array}$ & $\begin{array}{l}\text { Unutrašnja } \\
\text { motivacija }\end{array}$ \\
\hline $\begin{array}{l}\text { Percipirani } \\
\text { lokus uzročnosti } \\
\text { Spoljni }\end{array}$ & Eksterna & Donekle eksterna & Donekle interna & Interna \\
\hline $\begin{array}{l}\text { Kvalitet } \\
\text { ponašanja }\end{array}$ & Neodređeno (kontrolisano) & Samoodređeno (autonomno) \\
\hline
\end{tabular}

TSO se zasniva na prethodno navedenoj teoriji potreba, i u konkretnom slučaju identifikuje tri osnovne psihološke potrebe individue, i to [9]:

- $\quad$ potrebu za kompetencijom, koja odražava želju individue da se pronađu stvari koje treba da se urade i da se urade dobro.

- potrebu za povezanošću, koja se odnosi na povezanost individue sa drugima, odnosno osećaj zajedništva.

- potrebu za autonomijom koja predstavlja samoregulaciju od strane individue, a ne regulaciju indukovanu spoljnim silama.

TSO, kao nadogradnja TPP, predstavljene na slici 2, interpretirana je šemom na slici 5. 


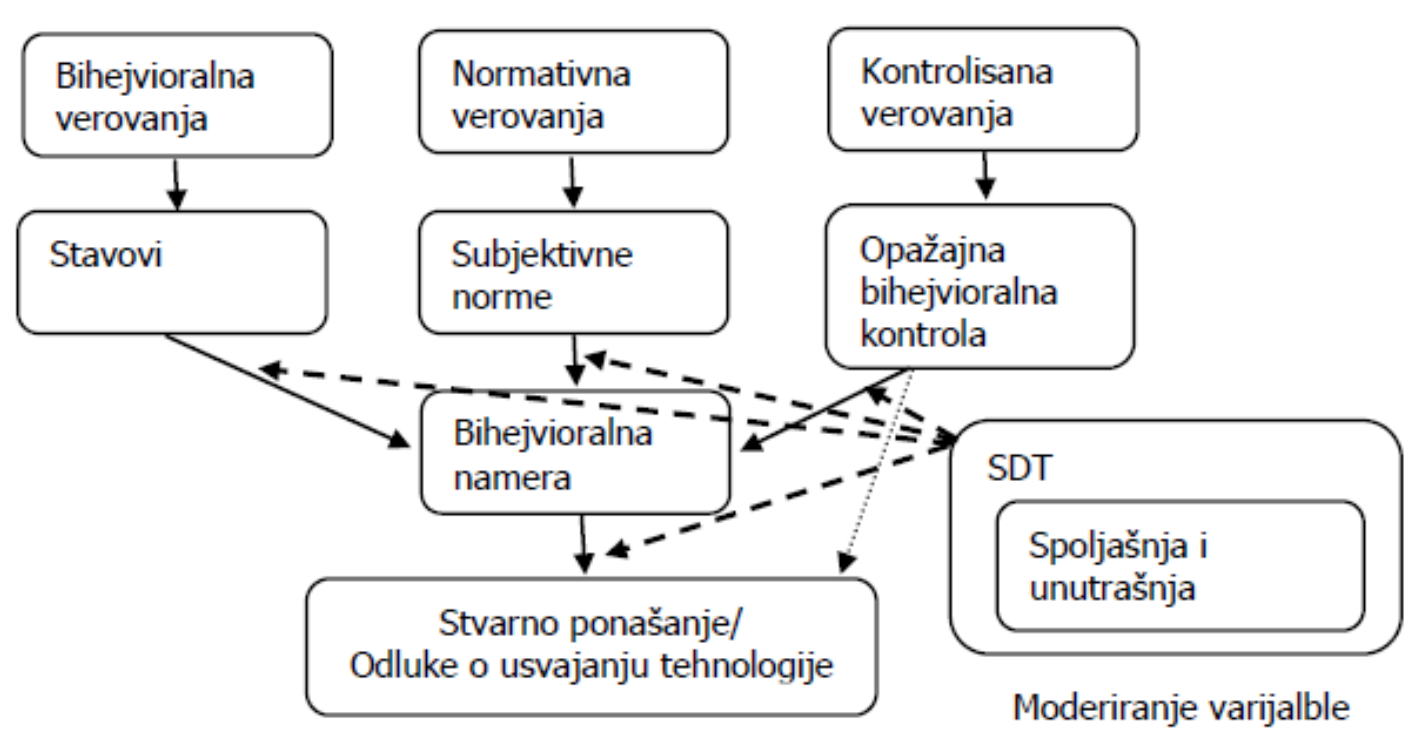

Slika 5: Dijagram Teorija samoodređenja (TSO) /Izvor: [9]

Na opisani način TSO /SDT/ postaje četvrta komponenta u okviru Teorije planiranog ponašanja (TPP).

\section{Zaključak}

U ovom radu je sprovedeno teorijsko desk top istraživanje bihejvioralnog ponašanja ljudskog faktora u poljoprivredi i to sa stanovišta motivacije i kontrole (upravljanja).

Budući da u poljoprivredi egzistiraju različite forme organizovanja, odnosno različiti oblici privrednih subjekata, i to kako velikih poljoprivrednih sistema (korporativnog tipa) pa sve do malih privatnih gazdinstava, to motivacija ljudskog faktora mora da se posmatra na dva načina.

Kad se radi o velikim poljoprivrednim sistemima (korporativnog tipa), sa razvijenom organizacionom strukturom, za koje se može reći da su pod kontrolom, motivisanje ljudskog faktora se može ostvariti primenom Teorije radne motivacije.

Kad se radi o ostalim tipovima poljoprivrednih sistema (nekorporativnog tipa), kod kojih je nedovoljno razvijena, ili uopšte ne postoji organizaciona struktura, motivisanje ljudskog faktora se može ostvariti primenom Teorije samoodređenja (TSO) u čijoj osnovi stoji Teorija planiranog ponašanja (TPP).

Dalje istraživanje na ovom planu bi trebalo usmeriti u pravcu preciziranja navedene diferencijacije poljoprivrednih sistema u pogledu njihove kontrole, tj., na kategorije sa razvijenom i na kategorije sa nedovoljno razvijenom ili bez bilo kakve organizacione strukture. 


\section{Bibliografija}

1. WIP. (2019). Istorija poljoprivrede . Retrieved from The Wikipedia the free Enciclopedia: https://sr.wikipedia.org/wiki/Istorija_poljoprivrede

2. FAO. (2018). World Food and Agriculture, Statistical Pocetbook 2018. Food and Agriculture Organization of the United Nation, Rome, pp. 1-254, http://www.fao.org/publications/card/en/c/CA1796EN.

3. ZPRR. (2016). Zakon o poljoprivredi i ruralnom razvoju, Službeni glasnik RS, 41/2009, 10/2013 - dr. zakon i 101/2016. Retrieved from TEHNOLOGIJA HRANE: https://www.tehnologijahrane.com/pravilnik/zakon-poljoprivredi-ruralnom-razvoju

4. HFIA. (2019,b). Human Factors In Agriculture. Retrieved from 3 ESO. Geography: https://sites.google.com/site/3oesogeography/6-primary-sector-activities/3-human-factors-inagriculture HFIA. (2019,a). Human factors in agriculture. Retrieved from Factors that influence farming:

http://www.edu.xunta.gal/centros/cafi/aulavirtual2/file.php/328/eXeLearning/Eulalia_Maria_ Simal_Iglesias/factors_that_influence_farming.html

5. FIA. (2019). Factors Influencing Agriculture: Human factors - Form 1 Agriculture Notes. Retrieved from EASYELIMU: https://www.easyelimu.com/high-schoolnotes/agriculture/form-1/item/465-factors-influencing-agriculture-human-factors

6. Popović R. (2014). Planiranje i upravljanje rizikom - ljudski faktor. Univerzitet u Novom Sadu, Ekonomski fakultet u Subotici, Departman za agrarnu ekonomiju i agrobiznis: 5.189.140.16/ svetodavstvo/sites/default/files/8.\%20Popovic\%20Rade.pdf.

7. Lapčević G, Krstić M. (2018). Research Of Risk In The Entrepreneurial Process . Conference EEE, 18-20 October 2018 (pp. 158-177). Belgrade, Serbia: BUSINESS MANAGEMENT, ENTREPRENEURSHIP AND ENTREPRENEURIAL TENDENCIES, Silver and Smith Publishers, London, UK .

8. Karavidić S., Cukanović-Karavidić M . (2016). Menadžment, Visoka škola za poslovnu ekonomiju I preduzetništvo, Beograd.

9. Shaman Herath C. (2010). Motivation As A Potential Variable To Explain Farmers' Behavioral Change In Agricultural Technology Adoption Decisions. Ekonomika A Management, No3/2010 , pp. 62-71. http://www.ekonomiemanagement.cz/download/1331826748_37a6/06_herat.

10. Keranović S. (2016). Motivacija za rad. Retrieved 03 05, 2016, from www.link.co.rs/media/Motivacija\%20za\%20rad.doc.

11. Bulat V. (2008). Menadžment, izmenjeno i dopunjeno izdanje. Kruševac: ICIM Plus.

12. Aleksić Glišović M., Jerotijević G., Jerotijević Z. (2019) Moderni pristup motivaciji zaposlenih, ЕКОНОМИКА, ISSN 0350-137X, EISSN 2334-9190, Vol. 65 (2) str. 121-133, doi:10.5937/ekonomika1902121A

13. Radović Marković M.,Marković D., Simović V. (2018) Informatičke kompetencije menadžera $i$ virtulenih timova, Trendovi u poslovanju, ISSN 2334-816X, Sveska 2.,Br.12, str.29-36

14. Cukanović Karavidic M., Karavidic S., Vujicic S. (2016),, Business education and social skills to leadership competencies, InternationalReview, No. 1-2/2016, Faculty of Business Economics and Entrepreneurship, Belgrade, ISSN 2217-9739, p.38-45

15. Krstić M. (2016). Industrijski menadžment. ICIM, Kruševac: ISBN 978-86-7566-044-6, COBISS.SR-ID 226675980.

16. Ryan, R., Deci, E. (2000). Self-determination theory and the facilitation of intrinsic motivation, social development, and well-being. American Psychologist, 55(1).

\section{Istorija rada:}

Rad primljen: 23.10.2019.

Prihvaćen: 25.11.2019. 